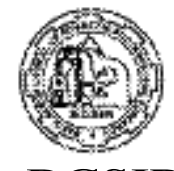

Available online at www.banglajol.info

Bangladesh J. Sci. Ind. Res. 44(1), 117-124, 2009

BCSIR

\begin{tabular}{c}
\hline BANGLADESH JOURNAL \\
OF SCIENTIFIC AND \\
INDUSTRIAL RESEARCH \\
\hline \hline
\end{tabular}

E-mail: bjsir07@gmail.com

\title{
Response of NPK Fertilizer on the Incidence of Pod Borer, Helicoverpa Armigera (Hubner) and Grain Yield of Chickpea
}

\author{
M. Altab Hossain, ${ }^{a^{*}}$ M. Z. H. Prodhan ${ }^{a}$ and M. Azizul Haque ${ }^{b}$ \\ ${ }^{a}$ Regional Agricultural Research Station, Ishurdi, Pabna and ${ }^{\boldsymbol{b}}$ Dept. of Entomology \\ Bangladesh Agricultural University, Mymenshingh, Bangladesh.
}

\begin{abstract}
Different dose of NPK fertilizer had shown both negative and positive influence on pod borer damage. In general, application of low to moderate doses of NPK reduced pod borer damage. Application of higher doses NPK increased pod borer damage compared to untreated control. Pod borer damage reduction by low to moderate doses of NPK fertilizer application ranged from 3.10 to $14.22 \%$. The highest pod damage reduction (14.22\%) was found in 20-20-20 kg NPK/ha followed by 40-20-20 kg NPK/ha (14.00\%) and 20-40-20 kg NPK/ha (12.42\%). While, pod borer damage was increased by higher dose levels of NPK fertilizer application which ranged from 4.34 to $15.81 \%$. Manuring with NPK fertilizer in chickpea increased grain yield upto $34.62 \%$. The highest yield $(1750 \mathrm{~kg} / \mathrm{ha})$ was obtained from 20 40-20 kg NPK/ha, which was statistically identical among levels of NPK application except 20-20-20 $\mathrm{kg} \mathrm{NPK} / \mathrm{ha}$. The lowest yield (1300kg/ha) was recorded from control treatment. The highest marginal benefit cost ratio (4.35) computed from the manurial combination 40-20-20 kg NPK/ha followed by 2040-20 kg NPK/ha (MBCR 3.73) Manurial combination 40-20-20 kg NPK/ha was found most profitable followed by $20-40-20 \mathrm{~kg} \mathrm{NPK} / \mathrm{ha}$ in considering pod borer damage and yield in chickpea cultivation.
\end{abstract}

Key words : Chickpea, Pod borer, NPK Fertilizer and Yield

\section{Introduction}

Chickpea, Cicer arietinum L. also known as gram, is one of the important pulse crops in Bangladesh. It is generally grown under rainfed or residual soil moisture conditions in rabi season. Chickpea is attacked by eleven species of insect pests (Rahman, et al 1982).
Among these, the pod borer, Helicoverpa (=Heliothis) armigera (Hubner) is the most serious one in most of the chickpea growing areas of the country (Begum et al, 1992). On an average, 30 to $40 \%$ pods were found to be damaged by pod borer with an average of

*Corresponding authour, 
400 kg/ha grain loss (Rahman, 1990).Under favourable conditions, pod damage due to this pest goes from 90 to 95 percent (Sachan and Katti 1994 ; Shengal and Ujagir 1990). Farmers are being reluctant to cultivate chickpea due to its susceptibility to pod borer. Pod borer has become the major constraint in chickpea production At present, effective control techniques other than insecticide application against the pest are not available (Hossain 2003). Insecticide is costly and not eco-friendly. Hence, there is a need to develop alternate method(s) to manage the pest. Agronomic practices like fertilizer application have been found to be very useful in controlling the pest of many other crops. Fertilizers are primarily applied to maintain high yield of a crop (Cooke 1982) but their use may have a direct effect on pest attack. This effect may be positive or negative (Coaker 1987). But until now there have been few investigations on the effect of fertilizers on pod borer incidence chickpea. The main objective of the study was to determine the effect of different levels of NPK fertilizer in suppressing the pod borer damage in chickpea.

\section{Materials and Methods}

The experiment was conducted at Regional Agricultural Research Station, Ishurdi, Pabna, Bangladesh during rabi seasons of 2004-05. There were three levels of nitrogen ( 0,20 and $40 \mathrm{~kg} \mathrm{~N} / \mathrm{ha})$, seven levels of phosphorus $(0,20,40,60,80,100$ and $120 \mathrm{~kg}$ $\mathrm{P}_{2} \mathrm{O}_{5} /$ ha) and five levels of potassium $(0,20$,
40, 60 and $80 \mathrm{~kg} \mathrm{~K} \mathrm{~K}_{2} \mathrm{O} / \mathrm{ha}$ ) were used in different combinations in 13 treatments viz., $\mathrm{T}_{1}=0-0-0, \mathrm{~T}_{2}=20-20-20, \mathrm{~T}_{3}=20-40-20, \mathrm{~T}_{4}=$ 20-60-40, $\mathrm{T}_{5}=20-80-40, \mathrm{~T}_{6}=20-100-60$, $\mathrm{T}_{7}=20-120-80, \mathrm{~T}_{8}=40-20-20, \mathrm{~T}_{9}=40-40-$ $20, \mathrm{~T}_{10}=40-60-40, \mathrm{~T}_{11}=40-80-40, \mathrm{~T}_{12}=40-$ $100-60$ and $T_{13}=40-120-80 \mathrm{~kg} / \mathrm{ha}$.

The experiment was laid out in randomized complete block design (RCBD) with three replications. The treatments were randomly allotted in each block. The unit plot size was $2 \mathrm{~m} \times 4 \mathrm{~m}$ with a distance of $50 \mathrm{~cm}$ between the plots and $150 \mathrm{~cm}$ between the replications. In unit plots row to row planting distance $50 \mathrm{~cm}$ and plant to plant $10 \mathrm{~cm}$. Each unit plot contains 4 rows of 4 meter length.

The whole amount of nitrogen, phosphorus and potassium were applied in the form of urea, triple super phosphate and muriate of potash as per treatments as basal at the time of sowing seeds. The seeds of BARI-chola 5 of chickpea were sown on November 30, 2004 in rows with the spacing of $50 \mathrm{~cm}$. The populations of the plant were maintained constant by keeping plant to plant distance of $10 \mathrm{~cm}$.

At maturity, all the pods were collected from 10 randomly selected plants from middle rows of each plot and examined. The damaged (bored) and total numbers of pods were counted and the percent pod damage was determined using the following formula:

$\%$ Pod damage $=\frac{\text { Number of damaged pods }}{\text { Total number of pods }} \times 100$ 
Plants of middle two rows avoiding border rows of each treatment comprising $4 \mathrm{~m}^{2}(1 \mathrm{~m}$ $\mathrm{x} 4 \mathrm{~m}$ ) area was harvested. The pods were then threshed; grains were cleaned and dried in the bright sunshine. The grain yield was obtained from each plot and converted it into per hectare.

The experimental data were analyzed by MSTAT-C software. The per cent data were transformed by square root transformation for statistical analysis. Mean comparisons for treatment parameters were compared using Duncan's Multiple Range Test (Steel and Torrie, 1960) at 5\% level of significance.

Net income and marginal benefit cost ratio (MBCR) due to fertilizer application were calculated on the basis of prevailing market prices of chickpea and fertilizers (urea. triple super phosphate and muriate of potash). Marginal benefit cost ratio was calculated as follows:

Marginal $\mathrm{BCR}=\frac{\text { Benefit on control }}{\text { Cost of treatment }}$

\section{Results and Discussion}

Table I. Effect of NPK fertilizer on pod borer damage

Twelve different combination levels of NPK fertilizers along with untreated control were evaluated against pod borer damage in chickpea. Tested combinations of NPK fertilizers had shown both negative and positive influence on pod borer damage. In general, application of low to moderate dose of NPK (20-20-20 kg NPK/ha to 40-60-40 kg $\mathrm{NPK} / \mathrm{ha}$ ) reduced pod borer damage compared to control treatment. The reason is not clear. However, it could be stated that such reduction of pod borer damage might be due to some complex mechanism occurring in the plant system in building up of anatomical features of pods in such a way that it may develop resistance power against the damaging activity of pod borer.

The lowest borer damage (15.19\%) was found in the plots treated with $20-20-20 \mathrm{~kg}$ NPK/ha followed by $40-20-20 \mathrm{~kg}$ NPK/ha (15.23\%). Application of 20-40-20 kg NPK/ha 20-60-20 kg NPK/ha, 40-40-20 kg NPK/ha and 40-60-40 kg NPK/ha received $15.51 \%, 15.94 \% 16.23 \%$ and $17.16 \%$ pod damage, respectively. The untreated control received $17.71 \%$ pod damage. Hence, it is observed that low to moderate dose of NPK received lower pod borer damage compared to control treatment.

Again, applications of higher doses of NPK (20-100-60 kg NPK/ha, 20-120-80 kg NPK/ha, 40-80-40 kg NPK/ha, 40-100-60 kg NPK/ha and 40-120-80 kg NPK/ha increased pod borer damage compared to untreated control. The highest pod damage (20.51\%) was recorded from the highest dose level (40-120-80 kg NPK/ha) followed by 40-80$40 \mathrm{~kg}$ NPK/ha (19.82\%), 20-120-80 kg NPK/ha (19.81\%) and 40-100-60 kg NPK/ha (19.68\%). This might be due to the higher 
Table I. Effect of NPK fertilizer on pod borer damage in chickpea

\begin{tabular}{l|l|l|l}
\hline Treatments & N-P-K (kg/ha) & $\begin{array}{l}\text { Pod damage } \\
\text { (\%) }\end{array}$ & $\begin{array}{l}\text { Pod damage increase (+) / } \\
\text { decrease (-) over control }\end{array}$ \\
\hline $\mathrm{T}_{1}$ & $0-0-0$ & $17.71(4.20)$ & - \\
$\mathrm{T}_{2}$ & $20-20-20$ & $15.19(3.89)$ & -14.22 \\
$\mathrm{~T}_{3}$ & $20-40-20$ & $15.51(3.91)$ & -12.42 \\
$\mathrm{~T}_{4}$ & $20-60-40$ & $15.94(3.99)$ & -9.99 \\
$\mathrm{~T}_{5}$ & $20-80-40$ & $16.99(4.11)$ & -4.07 \\
$\mathrm{~T}_{6}$ & $20-100-60$ & $18.48(4.29)$ & +4.34 \\
$\mathrm{~T}_{7}$ & $20-120-80$ & $19.81(4.44)$ & +11.85 \\
$\mathrm{~T}_{8}$ & $40-20-20$ & $15.23(3.89)$ & -14.00 \\
$\mathrm{~T}_{9}$ & $40-40-20$ & $16.23(4.03)$ & -8.36 \\
$\mathrm{~T}_{10}$ & $40-60-40$ & $17.16(4.14)$ & -3.10 \\
$\mathrm{~T}_{11}$ & $40-80-40$ & $19.82(4.41)$ & +11.91 \\
$\mathrm{~T}_{12}$ & $40-100-60$ & $19-68(4.43)$ & +11.12 \\
$\mathrm{~T}_{13}$ & $40-120-80$ & $20.51(4.53)$ & +15.81 \\
\hline
\end{tabular}

Values are the means of three replications.

Figures in the parentheses are the square root transformed mean values.

combined effect of NPK, the growth of the plants were more vigorous. The vigorous growth made the plants bushy rendering it more susceptible to pod borer. The bushiness of the plant provided better shelter to dark loving pod borer causing higher pod damage. Coaker (1987) cited that the use of fertilizers can also change the physiology of the plant making it more "active" as a host for an insect pest.

Pod borer damage reduction by low to moderate dose of NPK fertilizer application ranged from 14.22 to $3.10 \%$. The highest pod damage reduction (14.22\%) was found in 20-20-20 kg NPK/ha follwed by 40-20-20 $\mathrm{kg}$ NPK/ha (14.00\%) and 20-40-20 kg NPK/ha (12.42\%), 20-60-40 kg NPK/ha (9.99\%), 40-40-20 kg NPK/ha (8.36\%), 2080-20 kg NPK/ha (4.07\%) and 40-60-40 kg NPK/ha (3.10\%) respectively. On the other hand, pod borer damage increased by higher dose levels of NPK fertilizer application which ranged from 15.81 to $4.34 \%$. The highest level of pod damage increase (15.81\%) over control was found in the high- 
est dose of 40-120-80 kg NPK/ha followed by $40-80-40 \mathrm{~kg}$ NPK/ha (11.91\%), 20-120$80 \mathrm{~kg}$ NPK/ha (11.85\%), 40-100-60 kg NPK/ha (11.12\%) and 20-100-60 kg NPK/ha (4.34\%), respectively.

Therefore, it is concluded that low to moderate dose levels of NPK fertilizer influenced chickpea to received lower pod borer infestation but higher dose of NPK made plant bushy which influenced to receive higher pod borer infestation.
Table II. Effect of NPK fertilizer on yield of chickpea

Application of NPK fertilizer significantly increased grain yield. The highest yield (1750 kg/ha) was obtained from 20-40-20 kg NPK/ha, which was statistically identical among all dose lvevls of NPK application except $20-20-20 \mathrm{~kg}$ NPK/ha (1488 kg/ha). The lowest yield (1300 kg/ha) was recorded from control treatment.

Yield increased due to different dose levels of NPK fertilizer application ranged from

Table II. Effect of NPK fertilizer on yield of chickpea

\begin{tabular}{l|l|l|c}
\hline Treatments & N-P-K (kg/ha) & $\begin{array}{c}\text { Yield } \\
(\mathrm{kg} / \mathrm{ha})\end{array}$ & $\begin{array}{c}\text { Yield increased over } \\
\text { untreated control (\%) }\end{array}$ \\
\hline $\mathrm{T}_{1}$ & $0-0-0$ & $1300 \mathrm{c}$ & 00.00 \\
$\mathrm{~T}_{2}$ & $20-20-20$ & $1488 \mathrm{~b}$ & 14.46 \\
$\mathrm{~T}_{3}$ & $20-40-20$ & $1750 \mathrm{a}$ & 34.62 \\
$\mathrm{~T}_{4}$ & $20-60-40$ & $1671 \mathrm{a}$ & 28.54 \\
$\mathrm{~T}_{5}$ & $20-80-40$ & $1693 \mathrm{a}$ & 30.23 \\
$\mathrm{~T}_{6}$ & $20-100-60$ & $1650 \mathrm{a}$ & 26.92 \\
$\mathrm{~T}_{7}$ & $20-120-80$ & $1660 \mathrm{a}$ & 27.69 \\
$\mathrm{~T}_{8}$ & $40-20-20$ & $1694 \mathrm{a}$ & 30.30 \\
$\mathrm{~T}_{9}$ & $40-40-20$ & $1702 \mathrm{a}$ & 30.92 \\
$\mathrm{~T}_{10}$ & $40-60-40$ & $1640 \mathrm{a}$ & 26.15 \\
$\mathrm{~T}_{11}$ & $40-80-40$ & $1700 \mathrm{a}$ & 30.00 \\
$\mathrm{~T}_{12}$ & $40-100-60$ & $1679 \mathrm{a}$ & 29.15 \\
$\mathrm{~T}_{13}$ & $40-120-80$ & $1690 \mathrm{a}$ & 30.00 \\
\hline
\end{tabular}

In a column, treatment means having the same letter (s) are not significantly different by DMRT at \% level. Values are the means of three replications. 
$14.46 \%$ to $34.62 \%$. The highest yield increase (34.62\%) was recorded from 20-40$20 \mathrm{~kg}$ NPK/ha followed by 40-40-20 kg NPK/ha (30.92\%), 40-20-20 kg NPK/ha (30.30\%), 20-80-40 kg NPK/ha (30.23\%) and 40-80-40 kg NPK/ha (30.00\%). The lowest yield increase (14.46\%) was found in 20-20-20 kg NPK/ha. It was observed that fertilizer application increased grain yield significantly. Due to the effect of fertilizer, both the branching and pod setting was increased and subsequently grain yield was increased significantly. Prasad et al. (1985) reported the similar findings of yield increase in chickpea through phosphatic fertilizer application.

Table III. Effect of NPK fertilizer on net income marginal benefit cost ration

Net income and marginal benefit cost ratio (MBCR) of different levels of NPK fertilizer application in chickpea were differed among treatment (Table III). Application of 20-40$20 \mathrm{~kg}$ NPK/ha offered the highest net income (Tk 8870/ha) followed by 40-20-20 kg NPK/ha (Tk 8010/ha) and 40-40-20 kg NPK/ha (Tk 7400/ha.) The lowest net income (Tk 2460/ha) offered by the highest dose of 40-120-80 kg/ha. The highest marginal benefit cost ratio (4.35) offered by 4020-20 kg NPK/ha. The second and third highest MBCR 3.73 and 2.79 were comput- ed from 20-40-20 kg NPK/ha and 40-40-20 $\mathrm{kg}$ NPK/ha, respectively. The remaining other manurial combinations offered marginal benefit cost ratio less than Tk 2 .

Applications of NPK fertilizer in all 13 dose levels were not a always profitable due to higher market price of phosphorus and potassium fertilizers (Table III). The highest yield (1750 kg/ha) contributing manurial combination (20-40-20 kg NPK/ha) could not provided the highest marginal benefit cost ratio (MBCR) because of high market price of phosphatic fertilizer. The highest marginal benefit cost ratio (4.35) computed from the manurial combination 40-20-20 kg NPK/ha followed by $20-40-20 \mathrm{~kg}$ NPK/ha (MBCR 3.73) although the highest yield producing combination was 20-40-20 kg NPK/ha.

Hence, it is inferred that low to moderate dose levels of NPK reduced pod borer damage and higher doses increased borer damage although they were not differed significantly. Manuring with NPK fertilizer in chickpea increased grain yield significantly irrespective of pod borer damage. Considering profitability, manurial combination 40-20-20 kg NPK/ha was found most profitable followed by $20-40-20 \mathrm{~kg}$ NPK/ha in chickpea cultivation. 
Hossain, Prodhan and Haque

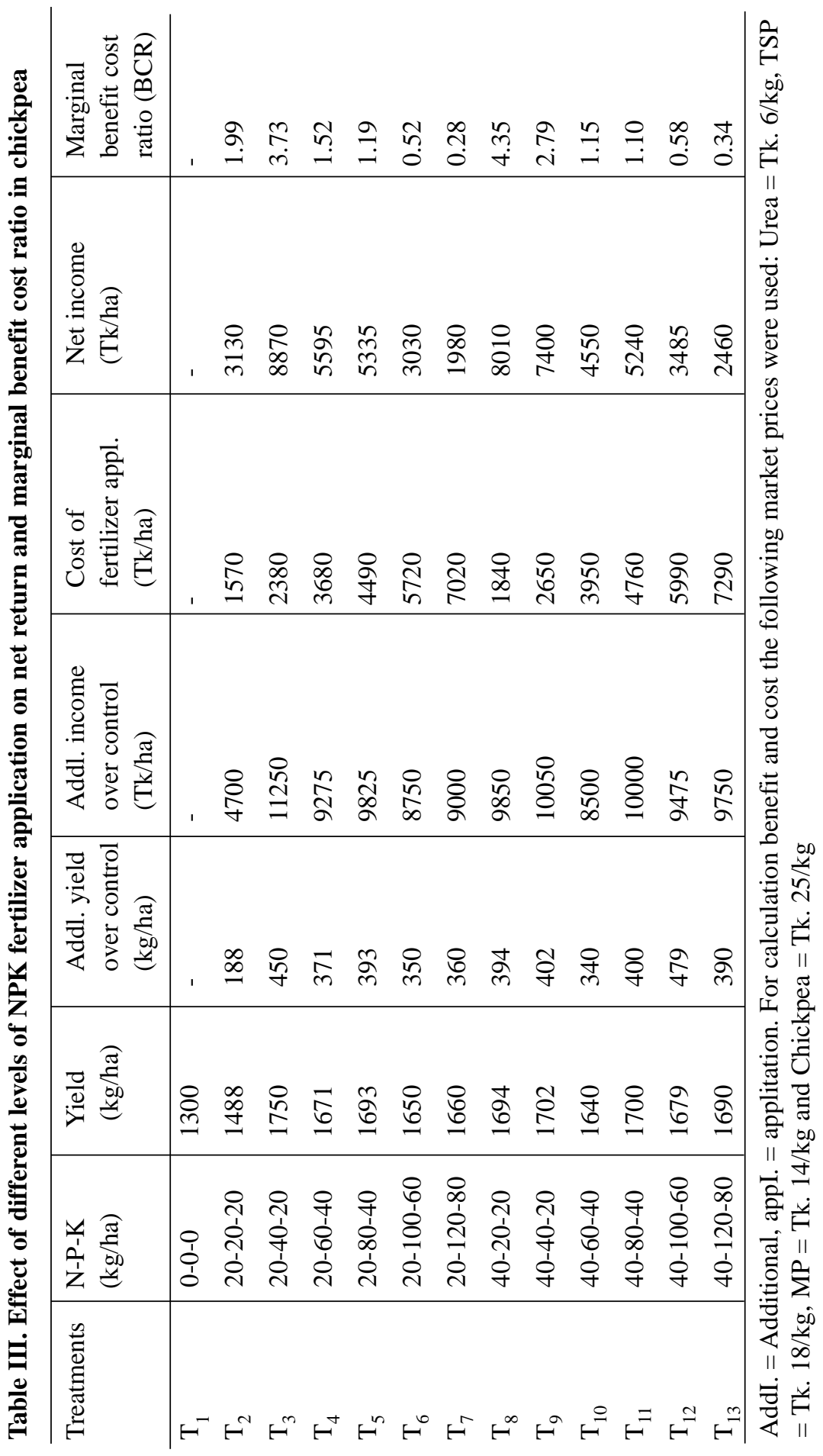




\section{References}

Begum, N. Hussain, M. Chowdhury, S.I. (1992). Effect of sowing date and plant density of pod borer incidence and grain yield of chickpea in Bangladesh. Int. Chickpea Newslet. 27: 19-21.

Coaker, T.H. (1987). Cultural Methods: the crop in Integrated Pest Management, eds A.J. Burn, T.H. Coaker and P.C. Jepson, Academic Press, London, PP. 69-88.

Cooke, G.W. (1982). Fertilizing for Maximum Yield. 3rd ed, Logman Scientific \& Technical. London.

Hossain, M.A. (2003). Management of chickpea pod borer, Helicoverpa armigera (Hubner) through intercropping and insecticide spraying. 36 (1): 51-56.

Prasad, D. Premchand, G.P. Srivastava. (1985). Effect of cultural practices on the incidence of chickpea pod borer, Heliothis armigera (Hubner). Indian J. Ent., 47(2): 223-225.
Rahman, M.M. Mannan, M.A. Islam, M.A. (1982). Pest survey of major summer and winter pulses in Bangladesh. In: Proceedings of the National Workshop on Pulses. August 18-19, 1981. Edited by A.K. Kaul. Bangladesh Agricultural Research Institute, Joydebpur, Dhaka PP. 265-273.

Rahman, M.M. (1990). Infestation and yield loss in chickpea due to pod borer in Bangladesh. Bangladesh J. Agril. Res., 15(2): 16-23.

Sachan, J.N. Katti, G. (1994) Integrated Pest Management. Proceeding of International Symposium on Pulses Research, April 2-6, IARI, New Delhi, India PP. 23-30.

Steel, R.G.D. Torrie, J.H. (1960). Principles and Procedures of Statistics, PP. 107-109. McGraw-Hill Bood. Co. Inc., New York.

Shengal,V.K. Ujagir, R. (1990). Effect of synthetic pyrethroids, neem extracts and other insecticides for the control of pod damage by Helicoverpa armigera on chickpea and pod damage-yield relationship at Patancheru in Northern India. Crop Protec. 9: 2932.

Received : September 25, 2007;

Accepted : March 23, 2008. 